\title{
Optimasi Waktu Inkubasi Lactobacillus rhamnosus SKG 34 Dalam Produksi Enzim Penggumpal Susu
}

\author{
Optimization of Incubation Time Lactobacillus rhamnosus SKG 34 in Production of \\ Milk Clotting Enzyme \\ Wulandari Setiadarma*, Dewa Gede Mayun Permana, Komang Ayu Nocianitri \\ Program Studi Ilmu dan Teknologi Pangan, Fakultas Teknologi Pertanian, \\ Universitas Udayana, Jl. Raya Kampus Unud, Jimbaran, Kuta Selatan, Badung-Bali \\ *Email: wulandarisetiadarma15@gmail.com
}

\begin{abstract}
This study aims to determine the effect of incubation time on milk clotting enzyme (MCE) activity produced by L. rhamnosus SKG 34 and determine the optimum incubation time to produce the highest its activity. This study used a randomized block design (RBD) with incubation time as a treatment consisting of 8 levels, that were 6 hours, 12 hours, 18 hours, 24 hours, 30 hours, 36 hours, 42 hours, and 48 hours. Data were analyzed with Variance Analysis (ANOVA) than followed by Duncan Multiple Range Test (DMRT). The analyzed were repeated 3 times resulting in 24 experimental units. The results showed that the incubation time significantly affected protease activity, MCE activity, specific protease activity and ratio of MCE to protease but did not affect the total LAB. The optimum incubation time of L. rhamnosus SKG 34 is 12 hours with total LAB $1.83 \times 10^{9} \mathrm{CFU} / \mathrm{ml}$ and protease activity $180.67 \mathrm{U} / \mathrm{ml}$, MCE activity $595.06 \mathrm{SU}$, protease spesific activity $73.149 \mathrm{U} / \mathrm{mg}$ and ratio of MCE to protease $3.29 \mathrm{SU} / \mathrm{U}$.
\end{abstract}

Keyword : Incubation time, Enzyme protease, Lactobacillus rhamnosus SKG 34, Milk clotting enzyme

\section{PENDAHULUAN}

Keju merupakan salah satu produk olahan susu yang mempunyai nilai gizi yang tinggi serta memiliki cita rasa yang khas. Secara umum, proses pembuatan keju meliputi beberapa tahapan yaitu pengasaman, penggumpalan, pemotongan curd, penggaraman, pencetakan dan pematangan. Menurut Rolet-repecaud et al., (2013) penggumpalan susu atau milk clotting merupakan tahapan penting pembuatan keju agar protein susu (kasein) dapat digumpalkan dan terbentuklah curd, sehingga matriks kasein menerangkap globula lemak, air, kalsium dan molekul lain. Adapun bahan yan dapat digunakan pada proses tersebut adalah enzim penggumpal susu atau milk clotting enzyme (MCE). Enzim yang umum digunakan yaitu enzim renin yang berdasarkan tata nama International Enzyme Nomenclature Comitee dinamai khimosin (Chymosin EC 3.4.4.3) (Muchtadi dan Ananda., 1989). Enzim renin termasuk golongan enzim protease yang dihasilkan dari lambung ke empat anak sapi (rennet), anak domba atau anak kambing. Enzim ini memiliki harga yang relatif mahal dan persediaannya yang terbatas. Adapun alternatif yang sudah dilakukan adalah mengganti enzim renin dengan enzim papain yang berasal dari getah papaya (Ashie et al., 2002), akan tetapi jumlahnya masih belum memenuhi kebutuhan maksimal industri keju. 
Saat ini banyak dilakukan pencarian sumber MCE dari berbagai jenis mikroba, produksi enzim dari mikroba ini memiliki beberapa keunggulan yaitu: terdapat berbagai jenis mikroorganisme yang dapat digunakan, proses pembuatanya relatif lebih mudah dengan waktu yang lebih singkat, bersifat lebih stabil dibandingkan dengan enzim yang berasal dari tumbuhan dan hewan (Ria et al., 2017). Pemanfaatan mikroorganisme untuk memproduksi enzim harus melalui proses seleksi terlebih dahulu terutama untuk industri pangan, mempunyai potensi alergi yang rendah dan tidak mengandung toksin oleh karena itu, mikroorganisme yang digunakan harus memenuhi kriteria generally recognized as safe (GRASS) (Winarno, 1995). Beberapa hasil penelitian telah ditemukan mikroba yang memproduksi enzim protease yang sifatnya hampir sama dengan renin, yaitu Mucor meihei (Birkjacer dan Jonk, 1985), Amylomces rouxii (Yu dan Chou, 2005), Bacillus subtilis B1 (Zhongyang et al., 2011), L. casei D11 (Rohmatussolihat et al., 2015).

Bakteri asam laktat (BAL) dapat dimanfaatkan sebagai penghasil MCE karena keamanannya untuk dikonsumsi, seperti pada $L$. casei D11 yang memiliki aktivitas MCE sebesar $8,471 \mathrm{SU}$ dengan aktivitas protease $3,28 \mathrm{U} / \mathrm{ml}$ (Rohmatussolihat et al., 2015). Selain itu adanya jenis BAL baru, yaitu L. rhamnosus SKG 34 yang berasal dari susu kuda sumbawa. Bakteri ini memiliki kelebihan dapat bertahan pada kondisi pencernaan in vitro. Uji in vitro L. rhamnosus SKG 34 mampu melewati simulasi kondisi lambung dengan $\mathrm{pH} 3$ dan 4, tidak mengubah asam folat primer (folat) menjadi asam folat sekunder (deoksikolat), serta dapat menghidrolisis garam empedu (Sujaya et al., 2008).

Menurut Budiman et al., (2009) mikroba mempunyai aktivitas metabolisme yang berbeda-beda pada fase pertumbuhannya. Pada masa pertumbuh terjadi fase adaptasi, fase pertumbuhan, fase stasioner dan fase kematian. Fase-fase pertumbuhan tersebut sangat berpengaruh terhadap aktivtias enzim yang dihasilkan oleh pada saat metabolisme mikroba tersebut. Seperti pada L. casei D11 yang menunjukan waktu inkubasi optimumnya pada 24 jam untuk menghasilkan MCE tertinggi (Rohmatussolihat et al., 2015), Bacillus sp. B1 menunjukan waktu inkubasi optimumnya pada 30 jam (Yuniati et al., 2015) dan L. delbrueckii menunjukan waktu inkubasi optimumnya pada 48 jam (Nuritasari, 2012). Oleh karena itu perlu dilakukan penelitian waktu inkubasi terhadap pertumbuhan L. rhamnosus SKG 34 agar mendapatkan waktu optimum untuk menghasilkan MCE, sehingga bakteri L. rhamnosus SKG 34 dapat berpotensi sebagai salah satu mikroba penghasil enzim penggumpal susu.

\section{METODE PENELITIAN}

\section{Tempat dan Waktu Penelitian}

Penelitian ini dilaksanakan di UPT. Laboratorium Terpadu Biosains dan Bioteknologi Universitas Udayana. Pelaksanaan penelitian ini dilakukan pada bulan Mei sampai dengan Agustus 2019.

\section{Bahan dan alat}

Bahan yang digunakan dalam penelitian ini adalah isolat Lactobacillus rhamnosus SKG 34 
(Koleksi UPT. Laboratorium Biosains dan Bioteknologi), de Man Rogosa and Sharpe (MRS) Broth (Oxoid), susu skim "merk" Greenfield, larutan $\mathrm{H}_{2} \mathrm{O}_{2}$, larutan lugol, pewarna safranin, alkohol 96\%, larutan saline 30\%, larutan gliserol $30 \%$, MRS Agar (Merck), buffer glisin (50Mm $\mathrm{pH}=9$ ), larutan $\mathrm{CaCl}_{2}$ 0,01M , BCA Protein Assay Kit II (BioVison), Trichloroacetic acid (TCA) 15\%, kasein, aquades, alkohol 70\%, kapas, plastik tahan panas, plastic wrap, almunium foil.

Alat-alat yang digunakan dalam penelitian ini adalah tabung raksi (pyrex), tabung effendorf, cawan petri, batang L, mikropipet, gelas ukur (iwaki), Laminar Air Flow (JSCB-900SB), erlenmeyer (pyrex), refrigerator, inkubator (memmert), beaker glass (pyrex), bunsen, blue tip, yellow tip,jarum ose, vorteks, kertas $\mathrm{pH}$, autoklaf, sentrifuse, $u V$ - visible Spektrofotometer (thermo scientific evolution 201), stopwatch.

\section{Rancangan Percobaan}

Rancangan percobaan yang digunakan pada penelitian ini adalah Rancangan Acak Kelompok (RAK) dengan perlakuan lama waktu inkubasi yang terdiri dari 8 taraf, yaitu: $\mathrm{A} 1=6 \mathrm{jam} ; \mathrm{A} 2=$ $12 \mathrm{jam} ; \mathrm{A} 3=18 \mathrm{jam} ; \mathrm{A} 4=24 \mathrm{jam} ; \mathrm{A} 5=30 \mathrm{jam}$; $\mathrm{A} 6=36 \mathrm{jam} ; \mathrm{A} 7=42 \mathrm{jam} ; \mathrm{A} 8=48$ jam. Masing-masing perlakuan diulang sebanyak 3 kali sehingga diperoleh 24 unit percobaan. Data yang diperoleh dianalisis dengan sidik ragam dan apabila perlakuan berpengaruh terhadap variabel yang diamati maka dilanjutkan dengan uji Duncan (Gomez dan Gomez, 1995).

\section{Pelaksanaan penelitian}

Tahap penelitian meliputi beberapa tahapan yaitu

\section{Penyegaran kultur}

Bakteri L, rhamnosus SKG 34 dilakukan penyegaran dengan cara dipipet $100 \mu 1$ kultur stok yang disimpan dalam gliserol $30 \%$ pada suhu $-20^{\circ} \mathrm{C}$ dan direfresh kedalam $5 \mathrm{ml}$ media MRS Brot steril dan diinkubasi secara aerob selama 24 jam dengan suhu $37^{\circ} \mathrm{C}$. Hasil positif ditunjukan dengan endapan putih dan kekeruhan pada media yang merupakan adanya aktivitas pertumbuhan dari bakteri tersebut.

\section{Uji Konfirmasi}

Konfirmasi isolat meliputi uji pewarnaan gram, uji katalase, dan uji gas (Suryani et al., 2010). Uji katalase dilakukan dengan membuat tetesan isolat pada gelas objek, kemudian ditetesi dengan dua tetes larutan $\mathrm{H}_{2} \mathrm{O}_{2}$, dan diamati gelembung yang timbul. Hasil positif ditunjukan oleh timbulnya gelombung udara $\left(\mathrm{O}_{2}\right)$ yang dihasilkan dari degradasi $\mathrm{H}_{2} \mathrm{O}_{2}$ oleh enzim-enzim katalase (Suryani et al., 2010).

Pewarnaan gram dilakukan dengan meneteskan isolat pada gelas objek kemudian difiksasi di atas bunsen dan diwarnai dengan kristal violet selama 1 menit, dicuci dengan air mengalir, kemudian ditetesi dengan larutan lugol selama 1 menit, dibilas dengan air mengalir. Selanjutnya gelas objek ditetesi alkohol 96\% selama 10 menit dan terakhir diwarnai dengan pewarna safranin selama 5 detik. Sel bakteri yang telah diwarna, dikeringkan dengan cara diangin-anginkan dan diamati dibawah mikroskop. Hasil positif ditunjukan berdasarkan warna bakteri yang dihasilkan, bakteri yang terwarnai dibagi menjadi dua kelompok yaitu: gram positif akan tampak berwarna ungu, 
sedangkan gram negatif akan tampak berwarna merah (Suryani et al., 2010).

Uji gas dilakukan dengan metode hot loop, dengan cara menusukan jarum ose panas kedalam suspensi biakan BAL. Hasil positif ditandai oleh terbentuknya gas $\mathrm{CO}_{2}$ dari hasil metabolisme glukosa (Suryani et al., 2010).

\section{Pembuatan stok isolat}

Stok isolat dibuat dengan cara mencuci sel L. rhamnosus SKG 34 yang sudah direfresh pada $5 \mathrm{ml}$ MRS broth kemudian disentrifugasi 1500 rpm selama 15menit, lalu supernatan di buang dan endapan ditambah dengan $3 \mathrm{ml}$ larutan salin dan divorteks kembali. Pencucian sel dilakukan sebanyak tiga kali, untuk yang ketiga kalinya larutan salin hanya di tambahkan $2 \mathrm{ml}$ kemudian divorteks, diambil $150 \mu$ l sel masukan kedalam tabung effendorf steril kemudian ditambahkan $150 \mu 1$ larutan gliserol 30\%. Stok isolat disimpan didalam kulkas dengan suhu $-20^{\circ} \mathrm{C}$.

\section{Persiapan sampel}

Stok isolat dipipet $100 \mu 1$ diinokulasi dalam $5 \mathrm{ml}$ media MRS Broth kemudian diinkubasi 24 jam pada suhu $37^{\circ} \mathrm{C}$, kemudian hasil inokulasi dipipet $100 \mu \mathrm{l}$ dan dibiakan dengan lama waktu 6 jam, 12 jam, 18 jam, 24 jam, 30 jam, 36 jam, 42 jam, 48 jam kemudian diinkubasi pada suhu $37^{\circ} \mathrm{C}$. Hasil positif ditunjukan dengan munculnya endapan putih dan kekeruhan pada media yang merupakan adanya aktivitas pertumbuhan dari bakteri tersebut. Enzim yang terdapat pada media produksi dipisahkan dari sel isolatnya menggunakan proses sentrifugasi dengan kecepatan 7.800 rpm selama 10 menit pada suhu $4^{\circ} \mathrm{C}$. Hasil supernatan adalah enzim ekstraseluler yang selanjutnya digunakan dalam pengujian aktifitas protease, aktivitas MCE dan kadar protein.

\section{Parameter yang diamati}

Parameter yang diamati dalam penelitian ini yaitu total BAL dengan metode Fardiaz (1993), aktivitas protease dengan metode Merheb et al., (2007), aktivitas MCE dengan metode Arima et al., (1970), kadar protein dengan menggunakan Kit Protein BSA (BioVision) dan rasio MCE yang dihitung dengan membagi aktivitas MCE dan aktivitas protease.

\section{HASIL DAN PEMBAHASAN}

Hasil analisis total bakteri asam laktat (BAL) dan kadar protein pada supernatan dapat dilihat pada Tabel. 1 dan hasil analisis aktivitas enzim protease, aktivitas MCE, aktivitas spesifik protease dan rasio MCE terhadap protease pada supernatan dapat dilihat pada Tabel 2.

\section{Total BAL}

Hasil analisis ragam menunjukan bahwa waktu inkubasi berpengaruh tidak nyata $(\mathrm{P}>0,05)$ terhadap total BAL. Penelitian ini menggunakan bakteri L. rhamnosus SKG 34 yang digunakan sebagai kultur tunggal untuk penghasil enzim penggumpalan susu. Fase adaptasi Keterangan: Huruf yang sama dibelakang nilai rata-rata pada kolom yang sama menunjukan berbeda tidak nyata $(\mathrm{P}>0,05)$ atau fase lag diperoleh pada jam ke-6 hingga jam ke-12, terlihat adanya kekeruhan pada media dan munculnya endapan putih tipis pada medium yang berisi inokulum sejumlah 
dengan jumlah populasi $1,27 \times 10^{9} \mathrm{CFU} / \mathrm{ml}$ hingga $1,83 \times 10^{9} \mathrm{CFU} / \mathrm{ml}$.

Tabel 1. Hasil analisis total BAL dan kadar protein pada supernatan

\begin{tabular}{ccc}
\hline Waktu Inkubasi & Total BAL $(\mathrm{CFU} / \mathrm{mL})$ & Kadar Protein $(\mathrm{mg} / \mathrm{mL})$ \\
\hline 6 jam & $1,27 \times 10^{9} \pm 0,07$ & $2,66 \pm 0,03 \mathrm{a}$ \\
$12 \mathrm{jam}$ & $1,83 \times 10^{9} \pm 0,22$ & $2,47 \pm 0,02 \mathrm{~b}$ \\
$18 \mathrm{jam}$ & $2,87 \times 10^{9} \pm 0,22$ & $2,41 \pm 0,03 \mathrm{c}$ \\
$24 \mathrm{jam}$ & $3,72 \times 10^{9} \pm 0,34$ & $2,40 \pm 0,02 \mathrm{c}$ \\
$30 \mathrm{jam}$ & $2,94 \times 10^{9} \pm 0,27$ & $2,40 \pm 0,02 \mathrm{c}$ \\
$36 \mathrm{jam}$ & $1,94 \times 10^{9} \pm 0,04$ & $2,42 \pm 0,02 \mathrm{c}$ \\
$42 \mathrm{jam}$ & $1,56 \times 10^{9} \pm 0,07$ & $2,43 \pm 0,02 \mathrm{bc}$ \\
48 jam & $1,33 \times 10^{9} \pm 0,07$ & $2,42 \pm 0,02 \mathrm{c}$
\end{tabular}

Keterangan: Huruf yang sama dibelakang nilai rata-rata pada kolom yang sama menunjukan berbeda tidak nyata $(\mathrm{P}>0,05)$

Fase log terjadi pada jam ke-18 hingga jam ke-24 dengan jumlah populasi 2,87 $\mathrm{x}$ $10^{9} \mathrm{CFU} / \mathrm{ml}$ hingga $3,72 \times 10^{9} \mathrm{CFU} / \mathrm{ml}$. Fase stasioner terjadi pada jam ke-24 sampai jam ke-30 dengan jumlah populasi $3,72 \times 10^{9} \mathrm{CFU} / \mathrm{ml}$ hingga $2,94 \times 10^{9} \mathrm{CFU} / \mathrm{ml}$. Ketika pertumbuhan sudah mencapai akan terjadi penurunan kecepatan pembelahan sel dikarenakan kadar nutrisi dan penimbunan zat-zat beracun dari hasil metabolit akan dapat menghambat kecepatan pembelahan sel sehingga sel mengalami fase kematian (Nuritasari, 2012). Fase kematian terjadi pada jam ke-36 hingga ke-48 dengan jumlah populasi 1,94 x $10^{9} \mathrm{CFU} / \mathrm{ml}$ hingga 1,33 x $10^{9} \mathrm{CFU} / \mathrm{ml}$. Pemanenan enzim dapat dilakukan pada waktu pertumbuhan maksimum mikroba, hal ini dikarenakan pada waktu tersebut mikroba akan menghasilkan sel dalam jumlah yang sangat banyak, sehingga enzim terproduksi lebih untuk membantu proses metabolismenya (Nuritasari,
2012). Akan tetapi terdapat beberapa jenis mikroba yang menghasilkan enzim protease pada saat fase lag pertumbuhannya, seperti pada Bacillus sp (Yuniati et al, 2015) dan L. casei D11 (Rohmatussolihat, 2015). Hal ini disebabkan pada saat fase lag bakteri akan membutuhkan energi lebih untuk beradaptasi dengan lingkungannya, sehingga enzim yang dibutuhkan untuk metabolisme sel akan terproduksi lebih banyak (Yuniati et al, 2015).

\section{Aktivitas enzim protease}

Hasil analisis ragam menunjukan bahwa waktu inkubasi berpengaruh sangat nyata $(\mathrm{P}<0,01)$ terhadap aktivitas enzim protease. Hasil penelitian menunjukan bahwa aktifitas protease yang dihasilkan sejalan dengan pertumbuhan $L$. rhamnosus SKG 34, waktu produksi enzim protease tertinggi dihasilkan pada fase log pertumbuhan sel yaitu jam ke-24 yaitu sebesar 
185,17 U/ml dan aktivitas enzim protease terendah dihasilkan pada fase kematian jam ke-48 sebesar 168,50 U/ml. Menurut Yunita (2012) semakin lama waktu pertumbuhan sel akan menyebabkan penurunan aktivitas enzim, hal ini dikarenakan pada pertumbuhan sel, enzim akan dihasilkan untuk membantu proses metabolismenya apabila jumlah substrat pada media pertumbuhan semakin berkurang maka laju katalitik enzim pun menurun.

Tabel 2. Hasil analisis aktivitas enzim protease, aktivitas MCE, aktivitas spesifik protease dan rasio MCE pada supernatan

\begin{tabular}{lcccc}
\hline $\begin{array}{l}\text { Waktu } \\
\text { Inkubasi }\end{array}$ & $\begin{array}{c}\text { Aktivitas Protease } \\
(\mathrm{U} / \mathrm{mL})\end{array}$ & $\begin{array}{c}\text { Aktivitas MCE } \\
(\mathrm{SU})\end{array}$ & $\begin{array}{c}\text { Aktivitas spesifik } \\
\text { protease }(\mathrm{U} / \mathrm{mg})\end{array}$ & $\begin{array}{c}\text { Rasio MCE } \\
(\mathrm{SU} / \mathrm{U})\end{array}$ \\
\hline 6 jam & $178,33 \pm 0,80 \mathrm{c}$ & $0 \pm 0,00 \mathrm{~h}$ & $67,13 \pm 0,99 \mathrm{f}$ & $0 \pm 0,00 \mathrm{f}$ \\
$12 \mathrm{jam}$ & $180,67 \pm 0,76 \mathrm{~b}$ & $595,06 \pm 4,28 \mathrm{a}$ & $73,15 \pm 0,89 \mathrm{c}$ & $3,29 \pm 0,018 \mathrm{a}$ \\
$18 \mathrm{jam}$ & $180,92 \pm 0,76 \mathrm{~b}$ & $537,32 \pm 3,46 \mathrm{~b}$ & $75,18 \pm 0,90 \mathrm{~b}$ & $2,97 \pm 0,010 \mathrm{~b}$ \\
$24 \mathrm{jam}$ & $185,17 \pm 0,52 \mathrm{a}$ & $517,99 \pm 3,24 \mathrm{c}$ & $77,27 \pm 0,80 \mathrm{a}$ & $2,80 \pm 0,07 \mathrm{~d}$ \\
$30 \mathrm{jam}$ & $181,42 \pm 0,52 \mathrm{~b}$ & $508,84 \pm 3,10 \mathrm{~d}$ & $75,49 \pm 0,67 \mathrm{~b}$ & $2,80 \pm 0,02 \mathrm{~d}$ \\
36 jam & $176,33 \pm 0,38 \mathrm{~d}$ & $503,51 \pm 3,04 \mathrm{e}$ & $72,97 \pm 0,32 \mathrm{c}$ & $2,86 \pm 0,011 \mathrm{c}$ \\
42 jam & $173,50 \pm 0,25 \mathrm{e}$ & $483,23 \pm 2,79 \mathrm{f}$ & $71,47 \pm 0,15 \mathrm{~d}$ & $2,79 \pm 0,027 \mathrm{de}$ \\
48 jam & $168,50 \pm 0,50 \mathrm{f}$ & $464,52 \pm 2,59 \mathrm{~g}$ & $69,63 \pm 0,70 \mathrm{e}$ & $2,75 \pm 0,015 \mathrm{e}$ \\
\hline
\end{tabular}

Keterangan: Huruf yang sama dibelakang nilai rata-rata pada kolom yang sama menunjukan berbeda tidak nyata $(\mathrm{P}>0,05)$

Pengujian aktivitas protease bertujuan untuk mengetahui kemampuan protease yang dihasilkan oleh L. rhamnosus SKG 34 untuk memecah protein menjadi ikatan peptida dan asam amino, karena hal ini akan mempengaruhi flavor atau citarasa yang terbentuk dalam pembuatan keju. Aktivitas protease yang berlebih mengakibatkan pemecahan protein berlebih sehingga menghasilkan $\mathrm{NH}_{3}$ yang bersifat basa sehingga timbul citarasa pahit (Walstra et al., 1999).

Aktivitas protease dari L. rhamnosus SKG 34 menghasilkan aktivitas yang lebih tinggi dibandingkan dengan aktivitas protease berasal dari L. casei D11 3,28 U/ml (Rohmatussolihat et al., 2012), Bacillus sp. B1 7,13 U/ml (Yuniati et al., 2015), Streptomyces ehimensis $1,55 \mathrm{U} / \mathrm{ml}$ (Arima et al., 1966), S. Rimosus $1,71 \mathrm{U} / \mathrm{ml}$ (Arima et al., 1966). Menurut Nilegaonkar et al., (2006) enzim protease dari B. cereus MCM B-328 yang diisolasi dari kulit kerbau memiliki aktivitas maksimum sebesar 126,87 $\mathrm{U} / \mathrm{ml}$, tingginya aktivitas yang dihasilkan diduga dari sumber galur bakteri tersebut yang memiliki kandungan protein tinggi dan perlu didegradasi mikroba untuk keberlangsungan hidupnya. Oleh karena itu, dapat dikatakan bahwa L. rhamnosus SKG 34 memiliki potensi sebagai bakteri penghasil protease karena sumber galurnya yang berasal dari susu kuda liar. 


\section{Aktivitas MCE (Penggumpalan Susu)}

Hasil analisis ragam menunjukan bahwa waktu inkubasi berpengaruh sangat nyata $(\mathrm{P}<0,01)$ terhadap aktivitas MCE. Hasil penelitian menunjukan bahwa aktivitas MCE tertinggi dihasilkan pada jam ke-12 sebesar 595,06 SU, semakin lama waktu pertumbuhan menyebabkan menurunnya aktivitas MCE. Hal ini diduga karena protease yang dihasilkan semakin meningkat sehingga MCE yang ada dipecah oleh protease. Menurut Merheb (2007) protease yang terbentuk pada waktu inkubasi tertentu dapat memecah fraksi protein yang terdapat pada media pertumbuhannya. Aktivitas MCE yang dihasilkan L. rhamnosus SKG 34 tergolong rendah jika dibandingkan dengan aktivitas MCE dari bakteri lain yang berpotensi sebagai pengganti rennet yaitu L. casei D11 8,47 SU (Rohmatussolihat et al., 2012). Hal ini disebabkan beberapa faktor yang mempengaruhi aktivitas enzim seperti $\mathrm{pH}$ dan substrat yang dipergunakan untuk produksi MCE masih kurang optimum, karena bakteri yang memproduksi enzim membutuhkan nutrisi sumber karbon utama bagi kebutuhannya agar metabolisme bakteri dapat bertindak sebagai induser bagi enzim (Yuniati et al,. 2015).

Milk clotting enzyme (MCE) merupakan bagian dari protease dan MCE berkerja memutus ikatan peptida pada rantai Phe105-Met106 pada kappa kasein (Macedo et al., 1993). Kasein memiliki 4 molekul yang terdiri dari kasein alpha s1, kasein alpha s2, beta kasein dan kappa kasein. Kappa kasein merupakan molekul kompleks yang memiliki asam amino esensial yang diperlukan oleh tubuh, akan tetapi tidak dapat dicerna dengan mudah. MCE dapat membantu proses pencernaan kappa kasein dengan meinaktifkannya memutus ikatan Phe105-Met106 sehingga kappa kasein dapat berikatan dengan ion kalsium dan dapat mengendap atau tergumpal sehingga dapat dicerna oleh tubuh (Arima et al., 1966).

\section{Aktivitas spesifik enzim protease}

Hasil analisis ragam menunjukan bahwa waktu inkubasi berpengaruh sangat nyata $(\mathrm{P}<0,01)$ terhadap aktivitas spesifik enzim protease. Hasil aktivitas protease spesifik tertinggi yang dihasilkan pada waktu inkubasi optimum ke-24 sebesar 77,26 U/mg. Aktifitas spesifik enzim protease diperoleh dengan cara membagi hasil aktivitas protease dengan kadar proteinnya (Yuniati et al., 2015). Karena pada supernatan terdapat beberapa senyawa yang ada pada media pertumbuhan bakteri tersebut, oleh karena itu aktivitas spesifik enzim menunjukan kemurnian suatu enzim yang ada pada supernatan tersebut. Semakin tinggi aktivitas spesifik, maka semakin tinggi pula tingkat kemurnian enzim tersebut. Hal ini disebebkan karena hilangnya protein non-enzim pada beberapa tahap pemisahan yang dilalui dalam pemurnian enzim (Wijaya, 2002).

\section{Rasio MCE terhadap protease}

Hasil analisis ragam menunjukan bahwa waktu inkubasi berpengaruh sangat nyata $(\mathrm{P}<0,01)$ terhadap rasio MCE terhadap protease. Hasil rasio MCE terhadap protease diperoleh pada waktu inkubasi optimum ke-12 sebesar 3,29 SU/U. Nilai rasio MCE diperoleh dengan cara membagi aktivitas MCE dengan aktivitas protease 
(Arima et al., 1966). Akan tetapi rasio yang didapatkan masih lebih rendah dibandingkan dengan rasio MCE rennet $4000 \mathrm{SU} / \mathrm{U}$ (hansen's tablet) (Arima et al., 1966), B. subtilis nato 2981 SU/U (Sheih et al., 2009), Aspergillus niger MC4 4000 SU/U (Channe and Shewale, 1998) dan Mucor pusillus F-27 2000 SU/U (Arima et al., 1966). Hal ini disebabkan aktivitas protease yang tinggi sehingga enzim protease lebih dominan berkerja untuk memecah kasein daripada MCE, karena MCE yang dicari untuk pengganti renin adalah MCE yang memiliki aktivitas MCE yang tinggi dengan aktivitas protease yang rendah, agar tidak merusak citarasa yang dihasilkan dan pembentukan tekstur ketika dipergunakan untuk proses pembuatan keju (Rolet-repecaud et al., 2013).

\section{KESIMPULAN DAN SARAN}

\section{Kesimpulan}

Berdasarkan hasil penelitian ini dapat disimpulkan sebagai berikut :

1. Waktu inkubasi pada L. rhamnosus SKG 34 berpengaruh nyata terhadap aktivitas enzim protease, aktivitas enzim penggumpalan susu (MCE), aktivitas spesifik protease dan rasio MCE, tapi berpengaruh tidak nyata terhadap total BAL.

2. Waktu inkubasi optimum dari L. rhamnosus SKG 34 ialah 12 jam dengan hasil total BAL $1,83 \times 10^{9} \mathrm{CFU} / \mathrm{ml}$ menghasilkan aktivitas protease 180,50 U/ml, aktivitas MCE 595,06 SU, aktivitas spesifik protease $73,15 \mathrm{U} / \mathrm{mg}$ dan rasio MCE terhadap protease 3,29 U/SU.

\section{Saran}

Perlu dilakukan penelitian lanjut mengenai konsentrasi supernatan untuk menghasilkan karakteristik keju. Perlu dilakukan penelitian lanjut mengenai suhu inkubasi dan $\mathrm{pH}$ medium terhadap enzim penggumpalan susu yang dihasilkan.

\section{DAFTAR PUSTAKA}

Arima, K., J. Yu, S. Iwasaki, and G. Tamura. 1970. Milk Clotting Enzyme from microorganisme Purification and crytallization of Mucor rennet from Mucor Pusillus. var. Lindt. Appl Microbiology, 16, 1727-1733.

Ashie, I. N., T. L. Sorensen, and P. M. Nielsen. 2002. effect of papain and a microbial enzyme on meat proteins and beef tenderness. journal of food science, 67(6), 2138-2142.

Birkkjaer, H., and P. Joehnk. 1985. Technological suitability of calf renet substitutes. International Diary Federation, 14-23.

Budiman, A.K. 2009. Protein dan asam amino. Universitas Sumatra Utara. Sumatra.

Dutt, K., G. K. Meghwanshi, P. Gupta, and R. K. Saxena. 2008. Role of casein on induction and enhancement of production of a bacterial milk clotting protease from indigenously isolated Bacillus subtilis. Letters in Applied Microbiology, 46(5), 513-518.

Fardiaz, S. 1992. Mikrobiologi pangan I. Jakarta: Gramedia Pustaka Utama.

Gomez, A. A. 1995. Prosedur statistik untuk penelitian pertanian (2 ed.). Jakarta: UI-Press.

Magda, A., E. El-Bendary, M. Moharam, and T. H. Ali. 2007. Purificationn and characterization of milk clotting enzyme produced by Bacillus sphaeriucs. Journal of Applied Sciences Research, 3(8), 695-699. 
Macedo Queiroz, I. J. Faro Carlos and M. Pires Euclides. 1993. Specificity and Kinetics of the Milk-Clotting Enzyme from Cardoon (Cynara cardunculus L.) toward Bovine K-Casein. Journal agricultural and food chemistry, 41(10).

Muchtadi, D. dan M, Ananda. 1989. Enzim dalam industri pangan. Bogor: Pusat Antar Universitas Pangan dan Gizi.

Nilegaonkar, S. S., V. P. Zambare, P. Kanekar, S. Saranik. 2006. Production and partial characterization of dehairing protease form Bacillus cereus MCM B-326. Bioresource technology. 98 : 1238-1245.

Nuritasari, Y. 2012. Isolasi dan seleksi mikroba penghasil enzim penggumpak susu (milk-clotting) dari pangan fermentasi sebagai pengganti renin dalam pembuatan keju. Skripsi tidak dipublikasikan. Bogor: Fakultas Teknologi Pertanian IPB.

Rohmatussolihat., M. Nurindah Sari, P. Lusdayanti, Y. Widyastuti, dan E. Sukara. 2015. Pemanfaatan Milk Clotting Enzyme dari Lactobacillus casei D11 Untuk Pembuatan Keju Mozarella. J. teknologi dan industri pangan, 26(1), 63-71.

Rolet-Repecaud., O. Berthier, F. Beuvier E, Gavoye, S. Notz, E, Roustel, S., . . . Achilleos, C. 2003. Characterization of the non-coagulanting enzyme fraction of different milk-cloting prepartion. LWT_food Sci Technol, 50, 459-468.

Sugiyono. 2004. Kimia Pangan. Jakarta: PT. Gramedia Pustaka Utama.

Sujaya, I. N., Y. Ramona, N. M. Utami D, N. P. Suariani, N. P. Widarini, K. A. Nocianitri, dan N. W. Nursini. 2008. Isolation and
Characterization of Lactic Acid Bacteria from Sumbawa Mare Milk. J.Vet, 9, 52-59.

Suryani., Yoni, A. B. Oktavia, dan S. Umniyati. 2010. Isolasi dan karakterisasi bakteri asam laktat dari limbah kotoran ayam sebagai agensi probiotik dan ensim kolestrol reduktase. Biota, 12(3), 177-185.

Susanti, R., dan F. Febriana. 2017. Teknologi enzim. Yogyakarta: CV Andi Offset.

Susanti E. V. H. dan S. R. D Ariani. 2003. Kloning Gen Penisilin V Asilase Dari Bacillus sp Melalui Pembuatan Pustaka Genom. Program Studi Kimia Jurusan FKIP. Universitas Sebelas Maret. Surakarta. 57125. biodiveritas. Vol 5, no 1 Hal 1-6.

Walstra, P., T.J. Geurts, A. Noomen, A. Jellema, and M.A.J.S. Van Boelkel. 1999. Diary Technology. Mawel Dekker, Inc. USA.

Winarno, F. 1995. Enzim pangan. Jakarta: PT. Gramedia Pustaka Utama.

Wijaya, S. 2002. isolasi kitinase dari Scieroderma columnare dan Trichoderma harzianum. Jurnal ilmu dasar. 3(1): 30-35.

Yuniati, R., T. Nugroho T, dan Puspita, F. 2015. Uji aktivitas enzim protease dari isolat Bacillus sp galur lokal Riau. JOM FMIPA, 1, 116-121.

Zhongyang, D., L. Shuangping, G. Zhenghua, Z. Liang, Z. Kechang, and S. Guiyang. 2011. Production of milk clotting enzyme by bacillus subtilis B1 from wheat bran. afrian jurnal of Biotechnology, 10(46), 9370-9378. 